\title{
TOTAL KNEE REPLACEMENT
}

\author{
by DR. J. P. VAN VUREN \\ M.B., B.Ch., F.R.C.S. Consulting Orthopaedic Surgeon, Medical School, University of Witwatersrand \\ and Strydom Hospital.
}

The concept of knee joint replacement is not new. Replacements with endoprostheses were attempted as far back as 1900. Recent advances in the development of biologically suitable materials and the application of biomechanical principles in the design of endoprostheses, have opened a promising field in replacement arthroplasty.

It must be noted that the knee replacement endoprostheses which are available today only replace the femoro-tibial articulation and are therefore not true total knee replacements. Patello-femoral pain and articulation problems are often a complication after a successful knee joint replacement arthroplasty, and research to replace this articulation is in progress at the present time.

Basically knee joint replacement endoprostheses fall into two categories:

(i) The Hinge Type consists of intramedullary femoral and tibial stems locked together at the knee joint with a mechanical hinge arrangement. This hinge may replace the femoral and tibial condyles partially or totally.

(ii) The Resurfacing Type of prosthesis replaces the articulating surfaces of the femoral and tibial condyles partially or totally.

The materials used in the manufacture of the conponents vary with the particular design and type of prosthesis. The hinge type originally consisted of Co.Cr. Steel components, but recent types include plastic components. The resurfacing type of endo-prothesis by and large consists of femoral $\mathrm{Co} . \mathrm{Cr}$. Steel alloy components and distal high density polyethylene tibial components.

\section{Indications}

The prime indication for knee replacement arthroplasty is at present confined to joint failure in patients suffering from rheumatoid arthritis, as an alternative to knee fusion. Replacement arthroplasty may also b: considered in selected cases of osteo-arthritis or in patients in whom hemi-arthroplasty of the knee has failed.

The patients with knee joint failure usually have two features in common, viz., pain and mechanical instability. The mechanical derangement may be due to ligamentous instability or contracture, or instability due to joint surface and bone destruction. The patients of ten present with all the above features of joint failure present in one or both knee joints.

Before the advent of knee joint replacement some 6 years ago, one would have offered the patient a knee fusion which would have provided him with a stable painless knee. In many cases this is still the procedure of choice today.

At present total knee replacement may offer the patient the possibility of a stable, painfree, yet mobile knee.

Patients in whom replacement arthroplasty is considered may be classified on a functional basis into three groups:

(i) Those leading mostly a wheelchair existence but who are able to transfer independently. (ii) Those using walking aids but with a limited walk. ing distance due to pain and instability.

(iii) Ambulant patients walking without support, but who are forced to use some means of support due to increasing pain and instability.

The physiotherapeutic experience that we have gained is confined to patients who have had one of the follow. ing types of arthroplasty:

(i) Freeman-Swanson.

(ii) Geomedic.

(iii) Polycentric.

\section{Outline of Operative Procedure.}

An almost straight median parapatellar skin incision is used to expose the joint capsule and underlying structures. The incision extends from the upper border of the suprapatellar bursa to the tibial tubercle. The joint is exposed by dislocating the patella laterally.

The prostheses are inserted after bone resection of the femoral and tibial condyles. The amount of bone resected will differ with the type of prosthesis used. The prosthetic components are usually fixed with bone cement.

The subcutaneous structures are closed with nonabsorbable sutures. Routine suction drainage is used. Attention to careful skin closure is essential.

The limb is placed in extension in a Robert Jones Bandage.

\section{Post-operative Regime.}

The patient is nursed with the limb elevated on pillows for two to three days. The dressing is removed on the third day and the wound inspected for any signs of sloughing. day.

The suction drainage is usually removed by the third

On the third day the limb is put into a Thomas Splint with a Pearson attachment and physiotherapy is commenced.

\section{Complications of Importance to the Physiotherapist}

(i) Wound Dehiscence. Total wound dehiscence may occur as an early complication, that is. on the third day when flexing of the knee is commenced, but may occur at any time up to the tenth day. This complication usually is found in patients with rheumatoid arthritis who have either had cortisone treatment in the past or are still being treated with cortisone. It is well known that delayed wound healing occurs in patients with rheumatoid arthritis.

(ii) Superficial Skin Sloughing. The complication, in our experience, is the result of too tightly applied skin sutures. The commonest site of sloughing is below the patella.

The above complications are important from the physiotherapeutic point of view. It has been our experience that such complications will retard the postoperative rehabilitation of the patient and may lead to loss of flexion. We feel it is important that the surgeon and the physiotherapist inspect the wound together on the third day and every day till the tenth day. If early skin sloughing is present the surgeon should guide the physiotherapist as to the range of flexion allowed by 
ing the knee and observing the wound for signs of dehiscence, thus allowing flexion within safe limits. The dehise of flexion may be increased or decreased accordange the condition of the wound.

ing to the cound dehiscence must be treated by immediate Tuturing, whereafter the physiotherapeutic management risuturing directed by the surgeon.

Dehiscence of the joint capsule without skin involveDethay occur. In our experience this complication moes not affect the early post-operative physiotherapy. does observation of the knee is necessary to avoid total dehiscence. Once wound healing is complete, the total may be left with an unstable knee due to dehiscence of the deeper structures. The cause of this instability is usually lateral dislocation of the patella in flexion.

The above are the only complications we have encountered in our small series of sixteen total knee replacements. The following are some of the complications which have been reported in literature:

(i) Infection - superficial and deep.

(ii) Dislocation of components.

(iii) Instability due to inadequate ligamentous support.

(iv) Residual patellar pain

(v) Peroneal nerve palsy.

\section{The Physiotherapy Management of Geomedic and Polycentric Knee Prostheses}

\author{
by KATHRYN LESLIE, \\ B.Sc. (Physiotherapy) (Witwatersrand)
}

\section{PRE-OPERATIVE MANAGEMENT.}

This is an important period for the Physiotherapist, as it gives her not only a chance to assess the patient, but also time to gain the patient's co-operation and confidence.

To date the total knee replacement arthroplasties have

ly been performed on patients severely affected with Theumatoid Arthritis. This means not only is the knee joint affected, but there is usually severe involvement of other joints. This must be considered throughout the treatment period as these patients are generally severely disabled and handicapped.

\section{1. i. Assessing the patient.}

Attention is drawn to the following:

(a) Assessment of All Joints. This is important as if for example the hands or elbows are severely affected by arthritis the patient may be unable to manage walking appliances and the operation would be postponed until this disability had been corrected as far as possible, enabling better function.

Particular attention must be paid to the strength of the hip and opposite knee muscle groups as these may require strengthening in order for the ambulatory phase to be successful.

(b) Assessment of the Involved Knee Joint. The strength of the quadriceps especially vastus medialis, is usually very weak which is due to a flexion contracture of the knee joint.
Other deformities, such as a genu varrus or valgum, may be present as well. There may be instability of the knee joint.

(c) Gait. If the patient is ambulant the type of walking aid used and the gait pattern must be noted.

I. ii. An explanation of the treatment procedure is outlined to the patient. The patient is taught a strong isometric quadriceps contraction emphasising 'locking' the knee and avoiding a knee lag. It is stressed that the post-operative success will depend on the patient's motivation and hard work.

\section{POST-OPERATIVE MANAGEMENT}

11. i. Immediate post-operative stage. (Day 1 to day 5).

The patient returns from theatre with the leg kept in extension by either a Robert Jones bandage or a full length Plaster of Paris cylinder. A porto-vac drain has been inserted and is removed 36 to 48 hours postoperatively. An antibiotic drip is given intravenously for the first 48 hours.

The first treatment consists specifically of localized breathing, circulatory exercises, and isometric quadriceps contractions. When the patient is more co-operative he must palpate the contractions and exercise for ten minutes hourly. The patient progresses to straight leg raising when the porto-vac drain is removed. The physiotherapist must check that not only hip flexors are being used but particularly quadriceps. Strengthening exercises for all hip muscles of both legs are added to the routine and progressed as the patient improves. Gentle knee flexion exercises to about $20^{\circ}$ are begun by day 3 . On day 5 the Robert Jones bandage is removed, the wound examined by the surgeon, and if the wound is healthy the range of flexion is progressed.

\section{II. ii. Bed Stage. (Day 5 to day 10).}

The patient's leg is elevated in a Thomas splint and Pearson knee flexion piece. The patient's leg is maintained in extension for 45 minutes of the 60 minutes. During this time isometric quadriceps contractions are done. This may be aided by placing a rolled towel under the calf to encourage the development of vastus medialis and full extension of the knee. The leg is also exercised for 15 minutes of the hour in increasing flexion, using a system of pulleys and hand controls. In this way flexion of $70^{\circ}$ to $80^{\circ}$ can be obtained. At first the flexion is passive; but as his strength and confidence improve, the movement is resisted.

This is a very effective method of gaining range and strength, since the patient is encouraged to exercise by himself.

When the patient has gained $70^{\circ}$ flexion the splint is removed and the next few days are spent strengthening and increasing the range of movement of the knee joint. The patient participates in an exercise programme consisting of:

(a) Knee pivots done over the side of the bed, using Proprioceptive Neuromuscular Facilitation techniques, such as hold-relax, and contract-relax, to increase range and strengthen the knee muscles. These are followed by slow reversals to consolidate the range gained. These techniques may be facilitated by the use of ice packs.

(b) Progressive resistance exercises to increase the strength of the quadriceps.

(c) Auto-resisted knee flexion and extension exercises.

(d) Prone lying (feet dorsiflexed), knee extension.

(e) General strengthening exercises for the hip. 
The range of flexion should never be gained at the expense of extension and therefore time is spent in emphasizing final knee extension and avoiding a knee lag. This may be achieved by placing a knee block or rolled towel under the thigh and extending the knee in inner range. As the patient's strength improves, resistance is added accordingly and rhythmical stabilizations may be used to establish a stable knee.

\section{AMBULATORY STAGES (day 10).}

The patient is allowed up partial weight-bearing, the walking aids varying according to the patient's disabilities. As many of the patients were either bedridden or severely handicapped prior to the operation, this stage is progressed slowly.

The first day is spent regaining balance. The patient is then allowed to walk keeping the knee in extension, to gain confidence. This is progressed to weight transference, emphasizing a flexed knee during 'push off', followed by an extended knee in the stance phase. Time is spent locking and unlocking the knee against resistance when standing. Before discharge, the patient is taught to climb stairs and encouraged to be as independent as possible.

During this stage it is important not to lose the range of flexion gained and to continue to strengthen the knee. Pool therapy is a useful modality to achieve this. The swimming exercises included are, specific Proprioceptive Neuromusular Facilitation techniques, mobilizing exercises and gait re-education.

Exercises included in the patient's home programme are reciprocal pulley spring exercises, lunging, deep knee bends, stepping up and down a block, and autoresisted exercises.

The patient is discharged with a stable, painfree knee, partial or full weight-bearing. The range of flexion gained is $90^{\circ}$ in a geomedic or $120^{\circ}$ in a polycentric prothesis.

\section{SUMMARY:}

Physiotherapy plays an important role in the postoperative management of geomedic and polycentric knee protheses. The treatment programme can be divided into various stages, viz.:

(1) Pre-operative Management. This includes an assessment of the patient and an explanation to the patient of the treatment procedure.

(2) Post-operative Management. This can be considered as an immediate post-operative stage (day 1 to day 5) during which time the patient does isometric quadriceps contractions and should gain $20^{\circ}$ flexion; and a Bed Stage (day 5 to day 10) during which time the range of flexion is increased and the knee muscles are strengthened.

(3) Ambulatory Stage (day 10). The patient is usually partial weight-bearing at first and is progressed to full weight-bearing.

The patient is usually discharged between two to three weeks with a stable but functional knee, and advised to follow a home programme of exercises.

\section{OPSOMMING:}

Physioterapie is hoegenaamd belangrik en essensieêl met die na-operatiewe behandeling van geomediese $e_{i}$ poliesentriese proteses.

Die behandeling word in verskillende stadiums verdeel:

(1) Voor-operatiewe behandeling. Die geestelike en fisiese toestand van die pasiënt word in aggeneem en die prosedure van alle behandeling word aan die pasiënt verduidelik.

(2) Na-operatiewe behandeling. Die onmiddelike $\mathrm{m}$ operatiewe behandeling begin vanaf die eerste dy en duur tot op die $5 \mathrm{de}$ dag, waar die pasiënt isometriese quadrisep kontraksie oefening doen totdat hy 'n fleksie posisie van $20^{\circ}$ kan behaal. Daarna kom die bed stadium vanaf die 5 de dag tot op die $10 \mathrm{de}$ dag waarby die pasiënt sy fleksie posisie vermeerder en sodoende die knie spiere versterk.

(3) Die ontwikkeling stadium begin na die 10de dag. Die pasiënt word eers net met gedeeltelike gewig met krukke behandel en met bevordering volle gewig op ge-opereerde liggamsdeel. Die pasiënt word gewoonlik vanaf twee tot drie weke na-operatief ontslaan met 'n stewige, maar normaal funksionerende knie plus 'n program van oefeninge wat tuis gedoen moet word

\section{REFERENCES:}

i. Radin (Eric L.), April (1973): 'Biomechanics of Knee Joints: Its Implications in the Design of Replacements.' Orth. Clin. of North America. Vol. $4: 2$, pp. 539 .

ii. Wilde Alan H., April (1973): 'Geometric Knee Replacement Arthoplasty: Indications for Operation and Preliminary Experience'. Orth. Clin. of' North America. Vol. $4: 2$, pp. 547.

iii. Riley Lee H., April (1973): "Geometric Total Knee Replacement: Operative Considerations.' Vol. $4: \tau^{-}$ pp. 561.

Article received December, 1974.

\section{OBITUARY}

\section{JANNIE KOEHORST}

It is with deep regret that we write of the death during April of Jannie Koehorst. He was almost completely blinded during the Western Desert Campaign during the last World War. He trained at St. Dunstan's and then set up practice in Bloemfontein, where he worked for many years. He was held in great regard and affection by all who knew him. He retired to Cape Town to pursue his favourite sport of deep sea sailing. This he did with characteristic courage that commanded the respect of his fellow-yachtsmen. Our deepest sympathy goes out to his wife and family. 